\title{
Idiosyncratic Migrations of Black Terns (Chlidonias niger): Diversity in Routes and Stopovers
}

\author{
Jan van der Winden ${ }^{1, *}$, Ruben C. Fijn ${ }^{1}$, Peter W. van Horssen ${ }^{1}$, Debby Gerritsen-Davidse ${ }^{2}$ \\ AND Theunis Piersma ${ }^{3,4}$
}

\author{
${ }^{1}$ Bureau Waardenburg, Section Bird Ecology, P.O. Box 365, 4100 AJ, Culemborg, The Netherlands \\ ${ }^{2}$ Landschapsbeheer Zuid-Holland, Oude Delft 116, 2611 CG, Delft, The Netherlands
}

\begin{abstract}
${ }^{3}$ Chair in Global Flyway Ecology, Animal Ecology Group, Centre for Ecological and Evolutionary Studies, University of Groningen, P.O. Box 11103, 9700 CC Groningen, The Netherlands
\end{abstract}

\begin{abstract}
${ }^{4}$ Department of Marine Ecology, NIOZ Royal Netherlands Institute for Sea Research, P.O. Box 59, 1790 AB Den Burg, Texel, The Netherlands
\end{abstract}

\author{
*Corresponding author; E-mail: jvdwinden@hetnet.nl
}

\begin{abstract}
By 2013, six of 27 Black Terns (Chlidonias niger) from four Dutch colonies that had received light level geolocators in 2010-2011 had been recaptured. All six recovered individuals migrated to West Africa, but whereas one individual flew there nonstop, the others made stops of varying length en route. These included flights of 2,000-6,000 $\mathrm{km}$ between major stopovers, achieving travel speeds over $1,000 \mathrm{~km} /$ day. In addition to the single previously known postbreeding stopover, Lake IJsselmeer, this work revealed postbreeding stopovers at the Alborán Sea, the seas near the Canary Islands and at the Banc d'Arguin, Mauritania. Staging durations varied between 2 and 35 days, and the longer the staging took, the longer the subsequent flights were. In the West African nonbreeding region, the Black Terns with geolocators staged at the Banc d'Arguin, the marine continental edge seas between Senegal and Liberia, and the Gulf of Guinea, or went as far south as the Benguela Current off Namibia. Most birds spent most of their time far offshore. Northward migration for the three birds with active geolocators took 38-39 days with staging episodes near the Canary Islands and in the Mediterranean west of Italy. One individual crossed the Sahara from Senegal to northern Algeria in 3 days. After arrival in Europe, travel speeds were lower than when in transit from West Africa. Even with a sample size of six, we showed that Black Terns are long-distance migrants with substantial individual variation in migration patterns, including the use of staging sites, stopover times and travel distances. The variation in itineraries may imply that the distribution of the marine resources they rely on are relatively unpredictable. It remains to be seen whether the variability seen here reflects differences in otherwise fixed individual strategies or whether Black Terns are truly highly flexible. Received 23 November 2013, accepted 10 January 2014.
\end{abstract}

Key words.-Africa, Black Tern, Chlidonias niger, geolocator, staging strategies, travel distances.

Waterbirds 37(2): 162-174, 2014

Eurasian Black Terns (Chlidonias niger niger) breed in freshwater marshes across the mid-latitudes but behave like pelagic seabirds outside the breeding season. They have a known northern-winter distribution that extends along the western African coasts from Mauritania in the north to the Namibian coast in the south (Cramp et al. 1985; van der Winden 2002). The rather few recoveries from over 15,000 Black Terns banded in the Netherlands (van der Jeugd 2013) have revealed a sparse picture of migration itineraries, although the spread of these recoveries suggests that there may be considerable individual variation (Fig. 1).

This lack of information on postbreeding movements of Black Terns has invited opposing ideas on their migration strategy. Van der Winden (2002) suggested, on the basis of heavy individuals among the tens of thousands Black Terns staging at Lake IJsselmeer in the Netherlands, that fat stores were large

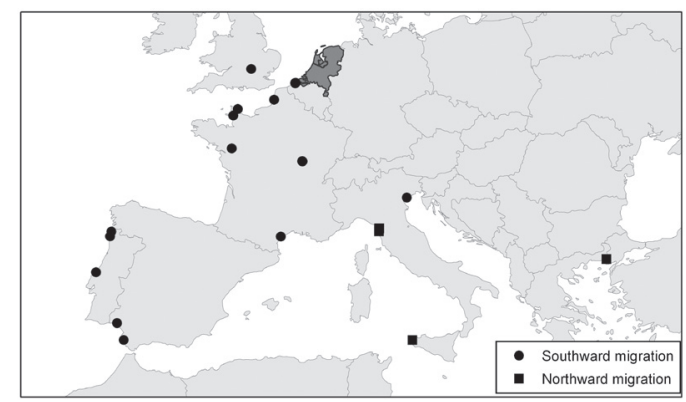

Figure 1. Band recoveries of Black Terns banded or recovered in the Netherlands in colonies or on staging sites, and banded or recovered during southward (JulySeptember; dots) or northward (April-May; squares) migration in Europe. 
enough to enable nonstop long distance flights to West Africa. This was consistent with Black Terns taking off with northerly tailwinds and the lack of large numbers observed anywhere along the Atlantic coast of Europe during this period. In contrast, on the basis of the rather lean birds encountered at an Italian postnuptial stopover site, Zenatello et al. (2002) suggested that postbreeding journeys would be characterized by short travel distances with many stopovers and en route feeding. After arrival in Africa, the information on movements and whereabouts is merely anecdotal, with an absence of information in December-February (van der Winden 2002).

While previous information on the southward migration has resulted in differences in opinion as to migration strategies, the information on northward migrations was too small to speculate about travel routes or flight times. Prior to the breeding season, in April-May, Black Terns are distributed in many types of freshwater bodies over the entire European continent (Haverschmidt 1978; Cramp et al. 1985). Such inland stopovers hold relatively small numbers (tens to hundreds of individuals). The few spring band recoveries in the eastern Mediterranean led Haverschmidt (1978) to suggest that Black Terns perform a loop migration. This would mean that the population as a whole has different migration routes in autumn and spring resulting in a loop.

The Eurasian Black Tern population is declining substantially in many parts of the breeding range (Birdlife International 2013). This is partly caused by habitat loss and deterioration of its quality in the breeding areas (van der Winden et al. 2004; van der Winden 2008b), but as the most important nonbreeding areas, including stop- overs, are insufficiently known, the population might be affected outside the breeding range. Sound conservation strategies can be developed only if we know the use of stopover and nonbreeding areas. The successful use of geolocators on other terns (Egevang et al. 2010; Nisbet et al. 2011; Fijn et al. 2013) provided the impetus to attempt to deploy geolocators on Black Terns, which are capable of carrying them as they are substantially larger than passerines (Bairlein et al. 2012). Still, a study using geolocators on Black Terns was challenging. First, the species breeds in freshwater habitats that are difficult to access, and although the species shows relative high regional site fidelity ( $\mathrm{J}$. van der Winden, unpubl. data), the locations of settlements shift from year to year. Also, as the birds do not spend much time sitting but fly most of the time, individuals with devices are difficult to detect and recapture. We affixed 27 geolocators to Black Terns at colony sites in the Netherlands and managed to retrieve six of the devices that provided the data for the analysis here. The main objectives of this study were to identify migration routes, timing, locations of stopover sites en route and long term staging sites in Africa.

\section{Methods}

Black Terns nest colonially, semi-colonially or solitarily in marshes; therefore, we refer to settlements or sites in this paper instead of colonies. The study area in the Province of South-Holland holds approximately 5060 settlements with a total of approximately 350 breeding pairs. This area is part of a larger, regional "Groene Hart" population with approximately 600 breeding pairs (van der Winden 2008a). In four settlements, a total of 27 Black Terns (17 males and 10 females; Table 1) were caught with nest traps in $2010(n=11)$ and $2011(n$ $=16)$. The settlements contained 10-30 pairs.

Table 1. Comparison of Black Terns deployed with leg-loop backpack loggers and tarsus band-loggers (2010-2013) to a control group of color banded birds (2002-2013). $\mathrm{M}=$ male, $\mathrm{F}=$ female.

\begin{tabular}{lccc}
\hline \hline Parameter & $\begin{array}{c}\text { Leg-loop Backpack Logger } \\
(\mathrm{M} / \mathrm{F})\end{array}$ & $\begin{array}{c}\text { Tarsus Band-Logger } \\
(\mathrm{M} / \mathrm{F})\end{array}$ & $\begin{array}{c}\text { Color Band Control } \\
(\mathrm{M} / \mathrm{F})\end{array}$ \\
\hline Number & $13 / 6$ & $4 / 4$ & $18 / 13$ \\
Return rate 2011-2013 (\%) & $46.1 / 50$ & $50 / 50$ & $69.1 / 50$ \\
Recaptured number & $1 / 1$ & $2 / 2$ & $\mathrm{n} / \mathrm{a}$ \\
Start nesting in return year & $0 / 1$ & $2 / 2$ & all \\
\hline
\end{tabular}


The Black Terns received archival light loggers (MK12 and MK20 geolocators; Fox 2010). In the absence of proven attachment techniques for Black Terns, we used elastic leg-loop backpack loggers ( $n=19$; Fox 2010; Lislevand and Hahn 2013) and tarsus band-loggers $(n=8$; Fox 2010). These latter devices were attached with Kevlar string and glued to a color band (mass of metal and color band, logger, string and glue: $1.5 \mathrm{~g}, \sim 2.3 \%$ of terns' body mass in the breeding period). The individuals with legloop backpack loggers received a color band on the tarsus to increase the resighting and recovery probabilities.

In two cases, both the male and the female of a pair were deployed with a logger. One of these males (ID 259; Fig. 2B) had already been banded as an adult on 12 December 2007 in Swakopmund, Namibia. The birds behaved normally after deployment and continued incubating. Data on breeding performance and duration of stay of the adults were collected from 16 pairs, of which at least one member had been equipped with a geolocator. Only one bird lost its clutch, while 15 others hatched their eggs successfully, so clutch survival was within the range of 61 to $93 \%$ as recorded for the population in the Netherlands (van der Winden et al. 2004). Five of the later recaptured birds had chicks at least one week after hatching. The duration of stay at the colony site of these birds was subsequently based on actual sightings of the birds with loggers and an estimated chick fledging period for the particular nest. This was used as a parameter to estimate staging time in the Netherlands after breeding activities if geolocator data did not show substantial movements.

From 2011-2013, at least 13 birds with loggers (48.1\%) were identified back at the colony sites, giving a return rate that is lower than the average of birds without loggers $(58.1 \%$; Table 1$)$. Six birds (three males and three females) were recaptured the next year or 2 years later-if missed in the first return year-with a nest trap, or on a day-roost with a clap net. For one of the pairs in which both partners were equipped with loggers (IDs 254 and 257), both birds were retrapped the next year at nests with new partners.

Of the 19 birds with leg-loop backpackloggers, two (10\%) were retrapped, and of the eight birds that had tarsus band-loggers, four $(50 \%)$ were retrapped (Table 1). Although return rates are comparable, we think that birds with band-loggers might have been in a slightly better condition and thus starting nesting more frequently. But sample sizes are too small to draw conclusions. At recapture, all birds were in good condition with no significant differences in body mass between initial capture and recapture (capture $=62.7 \pm 5.8 \mathrm{~g}$; recapture $=63.7$ $\pm 9.4 \mathrm{~g}$, paired sample $t$-test; $t=0.40, \mathrm{df}=5, P=0.71$, $n=6)$. However, the plumage of birds with tarsus bandloggers appeared to be in better condition than that of the two individuals with leg-loop backpack loggers (they were not in complete breeding plumage with a few white feathers remaining on the underparts, and one bird had more feather lice than are usually seen during the breeding season). All resighted birds with tarsus band-loggers started incubating after their return (Table 1). However, only one bird with a backpack-logger started breeding (Table 1).
The data from all retrieved loggers were downloaded successfully. The light data were processed with several components of the BASTrak software (Fox 2010). One geolocator failed after 63 days (31 July), and two others stopped collecting data after 247 and 235 days (4 February and 19 January). The three remaining loggers were still collecting data when retrieved after 1 year.

Transitions of light curves were assessed with TransEdit 2 with a light threshold of 10 . Two locations per day with an approximate accuracy of $\sim 180 \mathrm{~km}$ (Phillips et al. 2004) were calculated using Locator. One of the inputs for calculating locations from geolocator data is the angle of sun-elevation, which is the angle the sun makes with the light-sensor before it records either sunrise or sunset. Usually this angle is between 0 and $5^{\circ}$ below the horizon. We calculated this angle of sunelevation based on the calibration data with LocatorAid, and used -3.5 for the tarsus band-loggers and -4.3 for the backpack loggers. However, for three loggers alternative sun-elevation angles were chosen (respectively -3.0 and -2.5 for two tarsus band-loggers, and -3.5 for a backpack logger), based on logger-specific calibration data, the distribution of calculated locations in relation to continental land masses, and the presence of calculated locations in known unsuitable non-breeding habitat for Black Terns. Latitudes around equinoxes were unreliable and only included in the database after careful consideration of the light transitions and subsequent location. Noticeable disruptions in light curves were noted during processing, and locations were excluded from analyses when aberrant. To compensate for omitted locations, a straight-line path was assumed between the preceding and succeeding valid fixes to fill in for periods when locations were missing (mean \pm SD of $14 \pm$ $5.1 \%$ (range: $6.3-21.6, n=7$ ) of days). All geographical coordinates were stored in WGS84 datum, and subsequent spatial analyses and mapping were based on these data. Based on the average of the two daily positions, we calculated distances between positions. These distances are based on the shortest distances between two points on a sphere (great-circle distance). Staging sites were identified on the basis of decreases in the distances covered per day in the previously followed direction.

Subsequently, the extent of each staging site was calculated using adehabitatHR (Calenge 2006) in R (R Development Core Team 2012). Staging sites or stopovers were expressed in kernel density maps with a resolution of 0.16 by 0.16 degrees $(\sim 17 \times 15 \mathrm{~km})$. Kernel density calculations were performed if a minimum of five staging points were available. Map resolution and cut-off levels were based on visual inspection of the maps. Throughout the paper, individual Black Terns will be referred to the letter provided in Fig. 2 (A-D) or Fig. 3 (A and B).

\section{Results}

\section{Variation in Movements and Stopovers}

The six individuals showed substantial variation in routes and staging sites (Table 2; 
Table 2. Migration characteristics of Black Terns equipped with geolocators in breeding colonies in the Netherlands in 2010 and 2011. Six birds were followed on southward and three on northward migration (see Figures 2 and 3). Wind directions was obtained from the Royal Netherlands Meteorological Institute (2013). Migration speed was the calculated speed after departure from The Netherlands up to the (long-term) staging site in Africa including staging en route, and travel speed was calculated without staging en route.

\begin{tabular}{lr}
\hline \hline Migration Characteristics & \multicolumn{1}{c}{ Range } \\
\hline Estimated postnuptial period in The Netherlands & $6-47$ days \\
Departure date from The Netherlands & 9 July-30 August \\
Wind deviation direction from north at departure & $9-56^{\circ}$ \\
Distance to first staging site & $2,415-5,500 \mathrm{~km}$ \\
Duration at first stopover & $2-29$ days $(n=5)$ \\
Distance to second staging site & $1,240-6,225 \mathrm{~km}$ \\
Migration time until Mauritania $\left(20^{\circ}\right.$ N latitude) & $6-34$ days \\
Travel speed southward & $482-1,141 \mathrm{~km} /$ day \\
Migration speed southward & $208-916 \mathrm{~km} /$ day \\
Northward departure date $(n=3)$ & 21 March-3 April \\
First northward nonstop flight distance & $3,130-6,295 \mathrm{~km}$ \\
Travel speed northward & $160-1,245 \mathrm{~km} /$ day \\
Migration speed northward & $154-570 \mathrm{~km} /$ day \\
Total distance travelled (between staging areas) & $16,400-23,400 \mathrm{~km}$ \\
\hline
\end{tabular}

Figs. 2 and 3), as well as in the timing of their movements (Fig. 4). Five Black Terns spent the northern winter offshore in the region between Guinea-Bissau and Liberia, while one went as far south as Namibia. One (Fig. 3A) flew nonstop from the Netherlands to offshore Guinea-Bissau, while all others made stops in the Mediterranean (Figs. 2B-D), the seas near the Canary Islands (Figs. 2B and 3B), or at the Banc d'Arguin, Mauritania (Figs. 2A and 2C). The two birds of a pair (Figs. 2C and 2D) showed different timings, but the autumn and spring routes were quite similar. Travel speeds $($ mean $=694 \mathrm{~km} /$ day $)$ as well as migration speeds $($ mean $=445 \mathrm{~km} /$ day) varied substantially between individuals (Table 2; Figs. 2 and 3).

\section{Postbreeding Staging and Departure}

The time spent in the Netherlands after departing colony sites varied substantially between the six individuals. One Black Tern (Fig. 2B) lost its clutch and left the Netherlands 41 days after it was last seen in the colony (> 35 days after clutch loss). It is possible that within this period this bird made another nesting attempt somewhere else. The other birds were at least present in their colony sites until 1 week after their chicks hatched. From the moment of estimated departure of the colony, there was substantial variation in the duration of postnuptial staging in the Netherlands (6-47 days). The geolocator information is not accurate enough to be certain about staging at Lake IJsselmeer (van der Winden 2002), but the average latitude for four birds changed from $51.7^{\circ} \mathrm{N}(\mathrm{SD}=0.7)$ to $52.0^{\circ} \mathrm{N}(\mathrm{SD}=0.8)$ in the postbreeding period, suggesting northward movement from the breeding colonies to this important staging area. However, for two birds (Figs. 2B and 3A) the change was on average only $-0.2^{\circ} \mathrm{N}(\mathrm{SD}=0.4)$, indicating that birds did not visit Lake IJsselmeer.

The Black Terns with loggers left the Netherlands between 2 July and 30 August (Figs. 2 and 3). All birds left in periods with tailwinds from the NW to NNE (Table 2). Surprisingly, two birds (Figs. 2A and 3A) showed a 1-3 day movement toward the English Channel, but then returned to the Dutch North Sea region. For instance, individual 2A left the Netherlands in the evening of 5 July with northeasterly winds. On 6 July, the wind changed to westerly directions and during this period the bird returned to the northeast using the prevailing tailwinds. Its final departure was on 12 July, again on a day with a northeasterly tailwind.

Bird 3A showed similar behaviour in response to an adverse change in wind direc- 

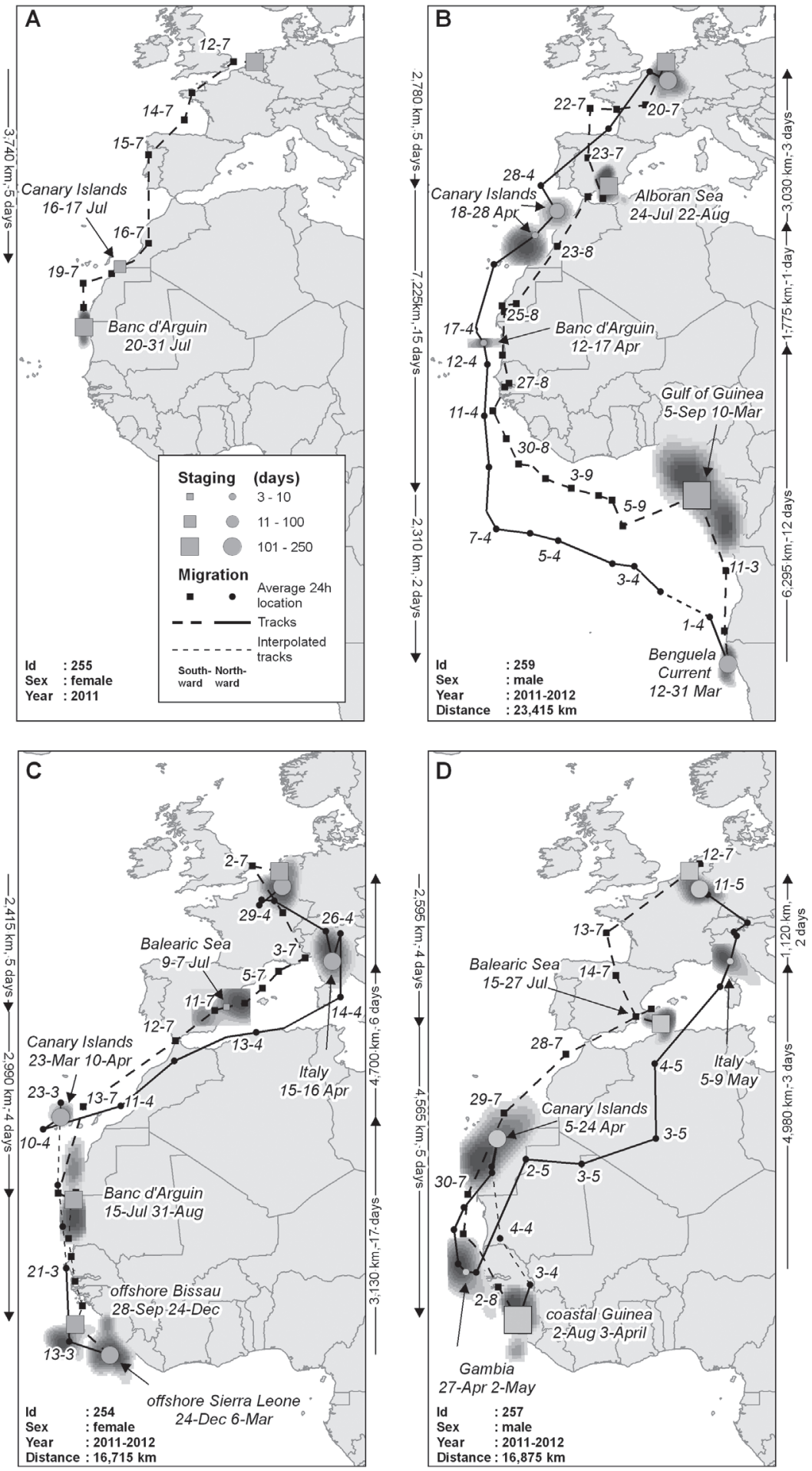

Figure 2. Migration routes, stopovers and staging sites during the nonbreeding season of four Black Terns captured in Dutch breeding colonies. Kernels indicate the range of staging areas as derived from the loggers and symbol size the duration of stay. Gray tones in the kernel maps range from 0 to $70 \%$ in steps of $10 \%$. Left and right of the panels, flight distance $(\mathrm{km})$ and speed (days) is presented for southward (left) and northward (right) migration between major staging sites. Map: Africa Equidistant Conic projection. 

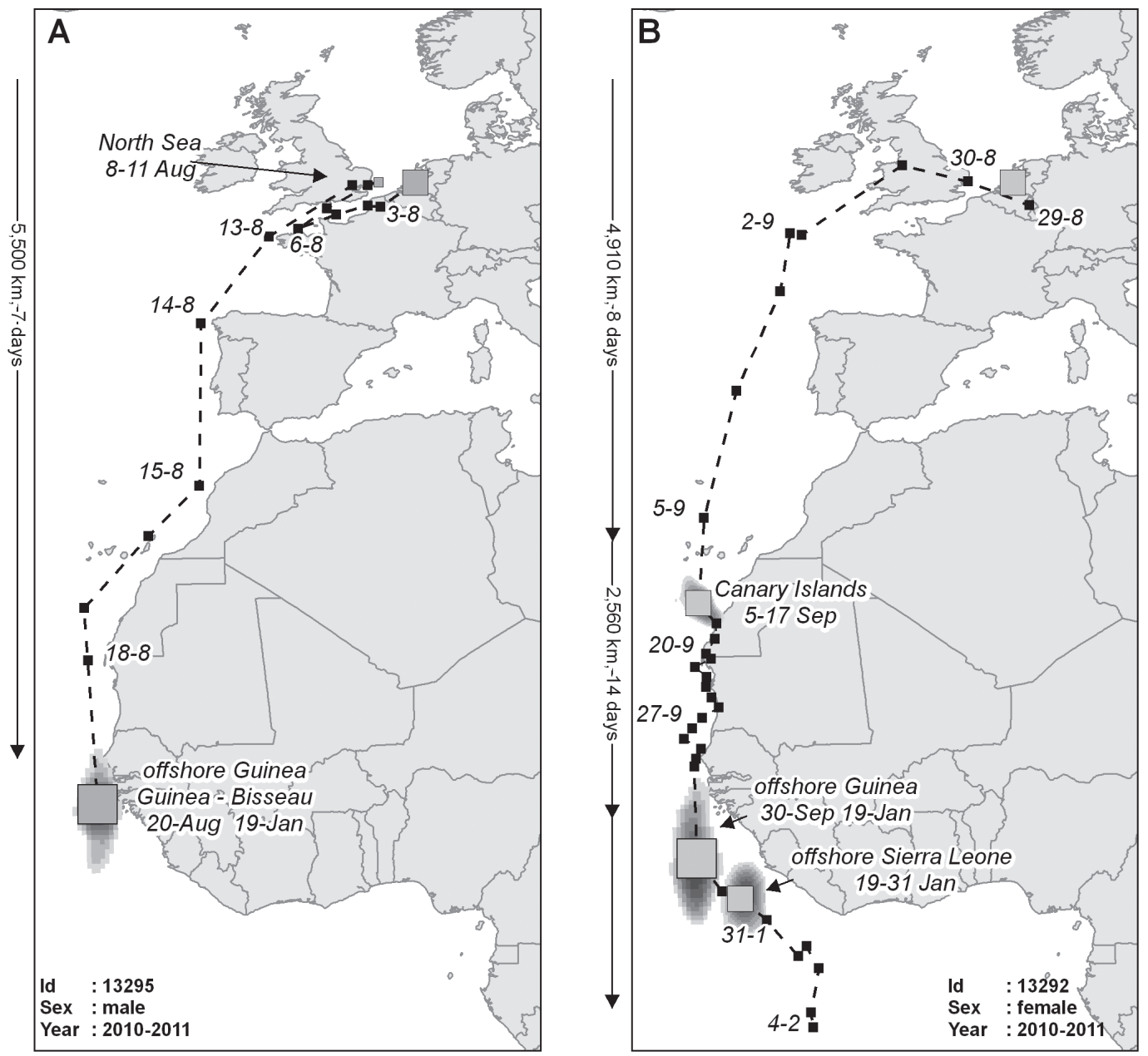

Figure 3. Migration routes, stopovers and staging sites during the nonbreeding season of two Black Terns captured in Dutch breeding colonies. See Fig. 2 for legend and additional explanation.

tion after initial departure. After a period with westerlies, the wind changed to a northwesterly direction $\left(310^{\circ}\right)$ on 4 August and the bird moved to the southwest. On $6 \mathrm{Au}-$ gust, it was near the Channel Islands as the wind direction changed again to westerlies. On 8 August, the Black Tern was back in the Netherlands. As the winds changed again to the NW $\left(340^{\circ}\right)$ on 12 August, the bird started its migration, without turning back.

Long Distance Nonstop Migration Flights to Africa with Variable Stopovers

The six Black Terns moved in different ways to West Africa. One bird (3A) flew 6 days nonstop from the Netherlands to the offshore areas near Guinea-Bissau, while all others made short or long stops in the Mediterranean (2B, 2C, 2D) or the Canary Islands region $(2 \mathrm{~A}, 3 \mathrm{~B})$. This means that the first flight between stopovers ranged from 2,415 to $5,500 \mathrm{~km}$, with an average travel speed of $753 \mathrm{~km} /$ day (range: 603-917 km/day). The duration at the first stopover also varied substantially (2-29 days). After the first stopover, the birds again showed a high variability in migration speed to the next staging site (range: $197-907 \mathrm{~km} /$ day, with an average of $728 \mathrm{~km} /$ day). The second staging site was situated at the Banc d'Arguin or at offshore areas between Senegal and Gabon (Figs. 2 and 3). 


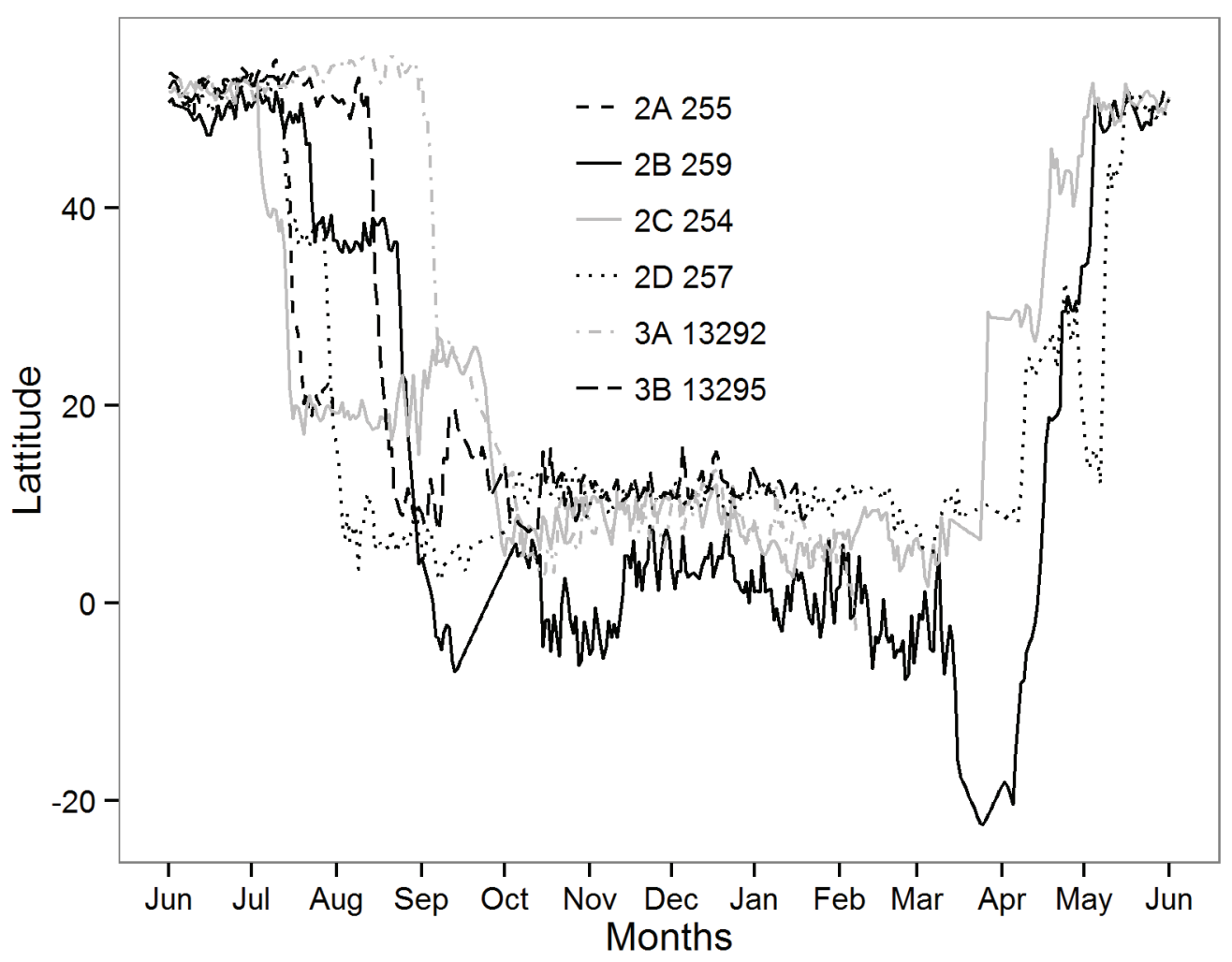

Figure 4. Migration timing during the nonbreeding season related to latitude of six Black Terns captured in Dutch breeding colonies. Average latitudes per day from 1 June onward are presented. ID = logger number and letters refer to panels in Figs. 2 and 3.

\section{Nearshore and Offshore Staging in Africa}

The arrival or passage date at $20^{\circ} \mathrm{N}$ latitude (region Banc d'Arguin; Table 2; Fig. 4) was highly variable, ranging from 14 July to 19 September. Three birds made their first long stop at Banc d'Arguin, and the others just passed this area to move to a more southerly staging site. Bird 2C first went to the Banc d'Arguin and then flew northward again to stop for 23 days offshore at the Western Sahara (Fig. 2C). Two birds with active geolocators left the Banc d'Arguin-Saharan region to the offshore areas between Senegal and Liberia, a region used for stopover or staging by most individuals. Within these offshore staging areas, the birds moved substantial distances (Figs. 2 and 3). Most individuals spent their time relatively far offshore mostly at the edge of the continental shelf. The distance to the coast of this shelf ranges from $300 \mathrm{~km}$ off Guinea-Bissau to $40 \mathrm{~km}$ near Liberia.
After having been initially banded there in 2007, individual 2B again moved to $\mathrm{Na}-$ mibia in the nonbreeding season of 20112012. It first went to the coastal areas and open seas of the Gulf of Guinea. In March, it moved further south to Namibia for a short stay of only 19 days. This bird flew substantial distances far offshore over the Atlantic Ocean (Fig. 2B).

Northward Migration to the Breeding Areas including Sahara Crossing

The migration characteristics of the three returning individuals varied as much as their southward migration characteristics. The onset of northward migration ranged from 21 March to 3 April. All birds staged between 10 and 19 days near the Canary Islands. Two birds continued their flight through the Mediterranean to the northwest coast of Italy for a 5- to 11-day stop. The data are not accu- 
rate enough to define the actual staging area in this region. One Black Tern crossed the Sahara nonstop, starting in the evening of 2 May and arriving in the Mediterranean in the morning of 4 May (Fig. 2D). It flew over Mauritania and Algeria toward the Mediterranean, moving approximately 3,000-5,000 $\mathrm{km}$ in 48 hours $(60-100 \mathrm{~km} / \mathrm{hr})$. Bird 2B left Namibia and made short 1- to 2-day stops along the route over the Atlantic Ocean and a 5-day stop at Banc d'Arguin. After a stop at the Canary Islands, it flew directly to the Netherlands. The migration duration from the first northward movements until arrival in the Netherlands (including staging) was exactly the same for all three birds (38-39 days). Migration duration from $20^{\circ} \mathrm{N}$ latitude to the Netherlands ranged from 8 to 38 days and depended on the location of the last stopover site (Figs. 2B-D).

\section{Discussion}

The variation in routes, timing and staging sites demonstrated in this sample of six individual Black Terns reflects the large spatial and temporal fluctuations in numbers seen at staging sites throughout the nonbreeding season (van der Winden 2002). In fact, these more detailed data emphasize the extent of individual variation and may reflect changing resources such as favorable winds and food.

For instance, thus far Lake IJsselmeer was presumed to be the only postnuptial staging area for Black Terns from Dutch colony sites. Here we showed that some birds were only briefly present at Lake IJsselmeer after breeding, and two individuals may not have used this area at all and instead migrated directly to alternative postnuptial staging sites in either the western Mediterranean or offshore of the Canary Islands. Recently, the staging numbers in Lake IJsselmeer have declined, reflecting either locally decreasing food resources or declining breeding populations (van der Winden 2008b). So, the use of postbreeding staging areas in the Mediterranean indicates that alternatives were available. Occasional sightings of large numbers from ships (e.g., Ash 1969) and band recoveries in southern Spain (Fig. 1) suggest that these areas can be used by large numbers of Black Terns.

The bypassing of Lake IJsselmeer is not consistent with the idea that a serious fattening period in the northern hemisphere is obligatory for a nonstop flight to West Africa (van der Winden 2002). Our findings indicate that Black Terns can use alternative stopover sites between West Africa and the breeding range. Four birds with stopovers of 15 to 40 days flew a maximum of $3,000 \mathrm{~km}$, while two birds with stopovers of more than 50 days moved more than 5,000 $\mathrm{km}$ nonstop (Fig. 4). However, the data also showed that migrating Black Terns were not spending substantial time (days) feeding en route as suggested by Zenatello et al. (2002). Long and fast flights between stopovers were found in all individuals, as well as departure on days with tailwinds (Table 2). This result is consistent with the assertion made by van der Winden (2002) that Black Terns maximize travel distance by storing fat and using tailwinds. Regardless of whether birds stopped at Lake IJsselmeer or in the Mediterranean, the subsequent flight between staging sites was at least 2,000 km up to 4,000 km (Figs. 2 and 3 ). We presume that birds headed for productive marine areas, and, since these areas vary within (Fig. 5) and between seasons, the birds may be more flexible than previously assumed.

With this new knowledge, lean birds and short stopover times in Italy might now be explained as emergency stops by birds that fail to find favorable tailwinds (ShamounBaranes et al. 2010). In this respect, the Uturn movements over the North Sea area in two individuals are also intriguing. These may have been failed migration attempts of birds that ran into unsuitable weather or unfavorable winds. Occasional sightings of briefly staging Black Terns along the coast of the U.K. in July-September (Wernham et al. 2002) also are likely to represent emergency stops.

The present results add to our understanding of the intriguing fluctuations in numbers along the African coasts during 

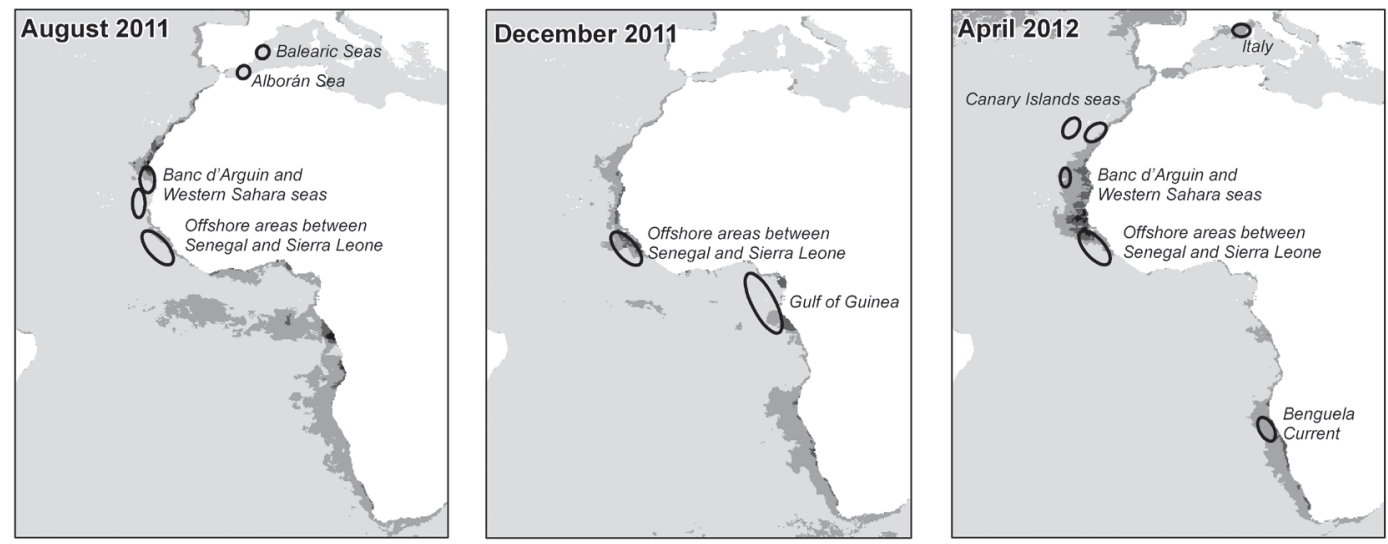

Figure 5. Marine productivity in the Mediterranean and along the African coasts during southward migration, northern winter and northward migration of Black Terns in 2011-2012. The intensity of the gray colors correspond with chlorophyll concentrations (O'Malley 2010). The circles indicate long term staging areas for individuals with geolocators in the corresponding month (see Figs. 2 and 3).

the nonbreeding season (van der Winden 2002). The changing numbers have been proposed to reflect changing food availability related to fluctuating intensities of marine productivity at upwellings. For instance, in August-October large concentrations of Black Terns are usually present at the Banc d'Arguin, coastal Senegal and Ghana. These areas can hold more than 100,000 individuals during this period, with a rapid decrease in numbers observed after October (Piersma and Ntiamoa-Baidu 1995; Camphuysen and van der Meer 2005; Camphuysen 2013). In February-March, the numbers are high again along the coasts of Namibia. In both seasons, warm northern waters border the colder Benguela Current waters. Invading warm water eddies into cold upwellings may cause mass shrimp mortality from which the Black Terns can profit (van der Winden 2002).

The data presented here confirmed the use of areas with high Black Tern numbers, but gave substantially more information on the movements between, and the use of, other key sites. The areas visited first in AugustSeptember are consistent with the known staging sites in coastal waters of Mauritania and Senegal. All six birds moved south after this period, but none stopped in the coastal waters of Ghana, although this area is a known staging site for Dutch Black Terns (Vogeltrekstation 2013). Instead, birds went to offshore areas between Senegal and Liberia, one of them as far as the Gulf of Guinea. The offshore area between Senegal and Liberia used by four birds during their entire nonbreeding season was unknown as a staging site, even though an offshore presence was indicated by anecdotal sightings from ships (Glutz von Blotzheim and Bauer 1982; Cramp et al. 1985). Our study confirmed that Black Terns spent substantial time far offshore moving between sites. Some individuals remained more than $100 \mathrm{~km}$ offshore, and even as far as $300 \mathrm{~km}$ off the coast of Guinea and Guinea-Bissau.

The lack of large numbers (hundreds) in January in well-studied coastal areas such Guinea or Guinea-Bissau (Diagana and Dodman 2006, 2007; Wetlands International 2012; B. Trolliet, unpubl. data) can now be explained by the offshore presence. The data points from inland Guinea (Fig. 2D) are likely caused by a logger deviation. Near the equator, deviations can occur in latitude (Fox 2010). Also clouds or shades caused by the bird itself might influence the lightdetection of the logger and thus day length (indicative for latitude), and, if this is asymmetrical, it affects the central point of the period between sunset and sunrise (indicative for longitude). It is most likely bird 2D had a coastal wintering range instead of a terrestrial one. Bird 2C also was closer to the coast more eastward between Sierra Le- 
one and Liberia (Fig. 2C), corresponding with records of large concentrations, such as in eastern Sierra Leone with up to 5,000 Black Terns (van der Winden et al. 2007) and 25,000 in Liberia (Gatter 1988).

Individual 2B provided some first indications of migration pathways of Black Terns concentrating in large numbers in coastal Namibia in the short period of February-March (Fig. 2B). This bird first spent months offshore and nearshore in the Gulf of Guinea between Nigeria and Gabon. Wallace (1973) already identified this area as important, as he claimed that Black Terns are the most common seabird across Nigerian waters. Close to the coast, Black Terns appear to be relatively scarce in this region (Schepers and Marteijn 1993). Bird 2B continued its migration to Namibia rather late in the season, in March (Fig. 2B). In a previous season $(2007 / 2008$,) this adult Black Tern already was present in Namibia in December. The variability of the itinerary of this individual suggests flexibility.

We presume that the intra-African movement patterns are induced by the availability of productive marine areas, but the variation between individuals resulted in different overall patterns. The productive marine areas vary within (Fig. 5) and between seasons, and the Black Terns seem to respond. Although Fig. 5 provides data on algae production, we do think they are relevant indications for Black Tern feeding areas. Black Terns feed on relatively small prey such as shrimp and small fish (van der Winden 2002). We expect the relation between algae production and plankton and fish abundance to be relatively strong and rapid.

Three individuals revealed an as yet unknown detail of northward movements, with striking variations in routes and timing. Two individuals stopped for a few days in April in the area between the Banc d'Arguin and the Western Sahara (Figs. 2B and 2D). Large flocks of Black Terns are known to be present there in late April (Tulp and Leopold 2004). However, the birds with loggers continued relatively quickly to the Canary Islands seas and staged there for at least 10 days. This area was not previously known as a stopover area during northward migration. Bird 2D provided the first proof of a nonstop northward flight over the Sahara for this species (Fig. 2D). Moreau (1967) lists only a few Saharan records and considered a desert crossing as problematic. However, Schmaljohann et al. (2008) recorded movements of unidentified terns over the Sahara, following more or less the same route as this Black Tern (Fig. 2D). These radar studies together with our data suggest that trans-Saharan flights may occur regularly. The movements to Italy explain the band recoveries on the western Italian coast in April-May (Fig. 1). Here, hundreds to thousands of Black Terns are present at freshwater lakes, river mouths, and coastal seas (L. Pardini and D. Derosa, pers. commun.) in a period when marine productivity increases (Fig. 5). Note that our birds did not show structural loop migration. One bird (Fig. 2C) took more or less the same route in autumn and spring through the Mediterranean while another (Fig. 2B) kept a western course in both periods.

The information collected with geolocators on even a few birds added immensely to our knowledge on the migration and staging strategies of Black Terns. Although data are still limited, we showed large variation in migration routes, staging sites and timing. Nevertheless, the idiosyncratic movements reported here are consistent with what we knew previously and also resolve the seemingly conflicting theories on their migration ecology. The rather large variation in postnuptial stopover time indicates that Black Terns basically store fat and fly longer distances, but might be able to minimize their fat storage and choose alternative stopovers. Throughout the nonbreeding season and northward migration, the differences in migration strategies remain. Similar large individual variation in sites used and timing of movements also has been documented for Common Terns (Sterna hirundo) breeding in North America and migrating southward along the eastern coast of South America (Nisbet et al. 2011). It is interesting that some individuals use different routes and staging sites, and even skip areas used by thousands of conspecifics. In seabirds, this individual 
variation in routes is not unusual (Gilg et $a l .2013)$, partly explained by wind-directed movements (González-Solís et al. 2009) and by spatial and temporal variation in marine productivity. In contrast, Fijn et al. (2013) showed a traditional strategy of well-defined stopovers and routes for Arctic Terns (S. paradisaea) migrating from the Netherlands to Antarctica.

The variation within and between tern species raises the question of whether the migration itineraries are fixed within individuals or whether individuals can perform differently between years. In shearwaters, variation is mainly explained by variation between individuals (J. González-Solís, pers. commun.). The use of geolocators on the same individual birds over several years will enable us to quantify the repeatability of their movements between years. The next step will be to combine data on wind (e.g., Shepard et al. 2013) and resource landscapes with movement data.

The passage of Black Terns through the Mediterranean during southward migration from the Netherlands raises questions about current population size estimates. The numbers of Black Terns passing Gibraltar (Hashmi 1996) and staging at Lake IJsselmeer (van der Winden 2002) were summed using the assumption that they represented two subpopulations with separate flyways. As we have shown here, birds using the Lake IJsselmeer flyway population (Netherlands-northern Russia) mix to an unknown extent with southeastern populations in the Mediterranean. This shows how careful we have to be in estimating flywaypopulation sizes based on visual migration for seabird species that might cross over land (e.g., Mateos-Rodríguez et al. 2012). Nevertheless, the new results can be used for the designation of Marine Important Bird Areas for Black Terns. Candidate areas (Fig. 5) should be the Balearic Seas, Alborán Sea, Canary Islands seas, Banc d'Arguin and Western Sahara seas, offshore areas between Senegal and Sierra Leone (continental edge), Gulf of Guinea, the Benguela Current, and yet to be identified coastal or marine areas in western Italy.

\section{ACKNOWLEDGMENTS}

This study is part of a Black Tern conservation program initiated by Landschapsbeheer Zuid-Holland, which partially funded the geolocators. The following farmers are thanked for their dedicated involvement in the project: M. Stolwijk, A. van Eijk, J. Verduijn and C. van de Bas. P. van den Ring and T. de Bruijn (Waterschap Rivierenland) and W. Reinink (Zuid-Hollands Landschap) allowed us to work on their properties. The following volunteers assisted with the project: M. Kruk, R. Meijer, A. Clements, C. Stam, A. Kooij, H. Borsje, J. Schoonderwoerd, J. Vlot, fam van Dijk, L. Kromwijk, J. den Hollander, and J. van Doorn. C. Camphuysen is thanked for information about offshore areas near Mauritania. B. de Bruijn (Vogelbescherming Nederland) provided funding for data analysis. M. Poot assisted with field work and discussions. H. van der Jeugd (Vogeltrekstation Netherlands) supplied band recovery data of "Dutch" Black Terns. R. Phillips (British Antarctic Survey) provided geolocators and advised during the analysis phase of this study. Three anonymous referees are thanked for their useful suggestions. The study is executed according to Dutch laws on bird capture and handling (bird capture and banding licence 936, Vogeltrekstation, Dutch Institute for Ecology, Wageningen).

\section{Literature Cited}

Ash, J. S. 1969. Black Terns feeding round surfacing fish and dolphins. Seabird Group Report 10: 48.

Bairlein, F., D. R. Norris, R. Nagel, M. Bulte, C. C. Voigt, J. W. Fox, D. J. T. Hussell and H. Schmaljohann. 2012. Cross-hemisphere migration of a $25 \mathrm{~g}$ songbird. Biology Letters 8: 505-507.

BirdLife International. 2013. Species factsheet: $C h$ lidonias niger. Cambridge, U.K. http://www.birdlife.org/datazone/speciesfactsheet.php?id=3292, accessed 10 February 2013.

Calenge, C. 2006. The package adehabitat for the R software: a tool for the analysis of space and habitat use by animals. Ecological Modelling 197: 516519.

Camphuysen, C. J. (Ed.). 2013. Ship-based seabird and marine mammal surveys off Mauritania, NovDec 2012. Unpublished report, NIOZ Royal Netherlands Institute for Sea Research, Texel, The Netherlands.

Camphuysen, C. J. and J. van der Meer. 2005. Wintering seabirds in West Africa: foraging hotspots off Western Sahara and Mauritania driven by upwelling and fisheries. African Journal of Marine Science 27: 427-437.

Cramp, S., D. J. Brooks, E. Dunn, R. Gillmor, P. A. D. Hollom, R. Hudson, E. M. Nicholson, M. A. Oglivie, P. J. S. Olney, C. S. Roselaar, K. E. L. Simmons, K. H. Voous, D. I. M. Wallace, J. Wattel and M. G. Wilson (Eds.). 1985. Handbook of the birds of Europe, the Middle East and North Africa: the birds of the Western Palearctic, vol. IV: terns to woodpeckers. Oxford University Press, Oxford, U.K. 
Diagana, C. H. and T. Dodman. 2006. Numbers and distribution of waterbirds in Africa 2002-2004, 2006. Wetlands International, Wageningen, The Netherlands.

Diagana, C. H. and T. Dodman. 2007. Coastal waterbirds along the West African Seaboard, January 2006. Wetlands International, Wageningen, The Netherlands.

Egevang, C., I. J. Stenhouse, R. A. Phillips, A. Petersen, J. W. Fox and J. R. D. Silk. 2010. Tracking of Arctic Terns Sterna paradisaea reveals longest animal migration. Proceedings of the National Academy of Sciences of the United States of America 107: 2078-2081.

Fijn, R. C., D. Hiemstra, R. A. Phillips and J. van der Winden. 2013. Arctic Terns Sterna paradisaea from the Netherlands migrate record distances across three oceans to Wilkes Land, East Antarctica. Ardea 101: 3-12.

Fox, J. W. 2010. Geolocator manual v. 8. British Antarctic Survey, Cambridge, U.K.

Gatter, W. 1988. Coastal wetlands of Liberia: their importance for wintering waterbirds. Study report No. 26, International Council for Bird Preservation, Cambridge, U.K.

Gilg, O., B. Moe, S. A. Hanssen, N. M. Schmidt, B. Sittler, J. Hansen, J. Reneerkens, B. Sabard, O. Chastel, J. Moreau, R. A. Phillips, T. A. Oudman, E. M. Biersma, A. A. Fenstad, J. Lang and L. Bollache. 2013. Trans-equatorial migration routes, staging sites and wintering areas of a High-Arctic avian predator: the Long-tailed Skua (Stercorarius longicaudus). PLoS ONE 8: e64614.

Glutz von Blotzheim, U. N. and K. M. Bauer (Eds.). 1982. Handbuch der Vögel Mitteleuropas, 8(II). Akademische Verlagsgesellschaft, Wiesbaden, The Netherlands.

González-Solís, J., A. Felicísimo, J. W. Fox, V. Afanasyev, Y. Kolbeinsson and J. Muñoz. 2009. Influence of sea surface winds on shearwater migration detours. Marine Ecology Progress Series 391: 221-230.

Hashmi, D. 1996. Migration of seabirds in the Straits of Gibraltar: scale of the movements, spatial and temporal course under consideration of daytime, tide and wind. Ph.D. Thesis, Max Planck Research Centre for Ornithology, Andechs, Germany.

Haverschmidt, F. 1978. Die Trauerseeschwalbe Chlidonias niger. Ziemsen Verlag, Wittenberg Lutherstadt, Germany.

Lislevand, T. and S. Hahn. 2013. Effects of geolocator deployment by using flexible leg-loop harnesses in a small wader. Wader Study Group Bulletin 120: 108-113.

Mateos-Rodríguez, M., L. Thomas and G. M. Arroyo. 2012. The development and use of a method to fill time gaps in migration counts. Condor 114 : 513-522.

Moreau, R. E. 1967. Water-birds over the Sahara. Ibis 109: 232-259.

Nisbet, I. C. T., C. S. Mostello, R. R. Veit, J. W. Fox and V. Afanasyev. 2011. Migrations and winter quarters of five Common Terns tracked using geolocators. Waterbirds 34: 32-39.

O’Malley, R. 2010. Ocean productivity. Oregon State University, Corvallis, Oregon. www.science.oregonstate.edu/ocean.productivity/index.php, accessed 30 September 2013.

Phillips, R. A., J. R. D. Silk, J. P. Croxall, V. Afanasyev and D. R. Briggs. 2004. Accuracy of geolocation estimates for flying seabirds. Marine Ecology Progress Series 266: 265-272.

Piersma, T. and Y. Ntiamoa-Baidu. 1995. Waterbird ecology and the management of coastal wetlands in Ghana. NIOZ Report 1995-6, Nederlands Instituut voor Onderzoek der Zee, Texel, The Netherlands.

R Development Core Team. 2012. R: a language and environment for statistical computing v. 2.15.2. R Foundation for Statistical Computing, Vienna, Austria. http://www.R-project.org, accessed 31 October 2013.

Royal Netherlands Meteorological Institute. 2013. Historical meteorological data from the Netherlands. Koninklijk Nederlands Meteorologisch Instituut, De Bilt, The Netherlands. http://www. knmi.nl/klimatologie/daggegevens/index.cgi, accessed 2 February 2013.

Schepers, F. J. and E. C. L. Marteijn. 1993. Coastal waterbirds in Gabon, winter 1992. WIWO report 41, Foundation WIWO, Beek-Ubbergen, The Netherlands.

Schmaljohann, H., F. Liechti and B. Bruderer. 2008. First records of Lesser Black-backed Gulls Larus fuscus crossing the Sahara non-stop. Journal of Avian Biology 39: 233-237.

Shamoun-Baranes, J., J. Leyrer, E. van Loon, E. Bocher, F. Robin, F. Meunier and T. Piersma. 2010. Stochastic atmospheric assistance and the use of emergency staging sites by migrants. Proceedings of the Royal Society Biological Sciences 277: 15051511 .

Shepard, E. L. C., R. P. Wilson, W. G. Rees, E. Grundy, S. A. Lambertucci and S. B. Vosper. 2013. Energy landscapes shape animal movement ecology. American Naturalist 182: 298-312.

Tulp, I. Y. M. and M. F. Leopold. 2004. Marine mammals and seabirds in Mauritanian waters. Unpublished report 04.020, Animal Sciences Group, Wageningen UR, The Netherlands.

van der Jeugd, H. 2013. Ringverslag 2012. Op het Vinkentouw 127: 17-32.

van der Winden, J. 2002. The odyssey of the Black Tern Chlidonias niger: migration ecology in Europe and Africa. Ardea 90: 421-435.

van der Winden, J. 2008a. Aantallen en broedsucces van de Zwarte stern in Nederland in 2006. Het Vogeljaar 56: 3-9.

van der Winden, J. 2008b. A review of population estimates of the Eurasian Black Tern Chlidonias niger niger. Vogelwelt 129: 47-50.

van der Winden J., A. J. Beintema and L. Heemskerk. 2004. Habitat-related Black Tern Chlidonias niger 
breeding success in the Netherlands. Ardea 92: 53-61.

van der Winden, J., A. Siaka, S. Dirksen and M. J. M. Poot. 2007. Waterbirds in coastal wetlands of Sierra Leone, January-February 2005. WIWO report \#84. Foundation WIWO, Beek-Ubbergen, The Netherlands.

Vogeltrekstation. 2013. Online species map with ring recoveries of Black Tern. Vogeltrekstation, Heteren. http://www.griel.nl, accessed 1 November 2013.

Wallace, D. I. M. 1973. Sea-birds at Lagos and in the Gulf of Guinea. Ibis 115: 559-571.
Wernham, C. V., M. P. Toms, J. H. Marchant, J. A. Clark, G. M. Siriwardena and S. R. Baillie (Eds.). 2002. The migration atlas: movements of the birds of Britain and Ireland. T. \& A.D. Poyser, London, U.K.

Wetlands International. 2012. International waterbird census overview 2012. African-Eurasian Region. Wetlands International, Wageningen, The Netherlands.

Zenatello, M., L. Serra and N. Bacetti. 2002. Tradeoffs among body mass and primary moult pattern in migrating Black Terns Chlidonias niger. Ardea 90: 411-420. 